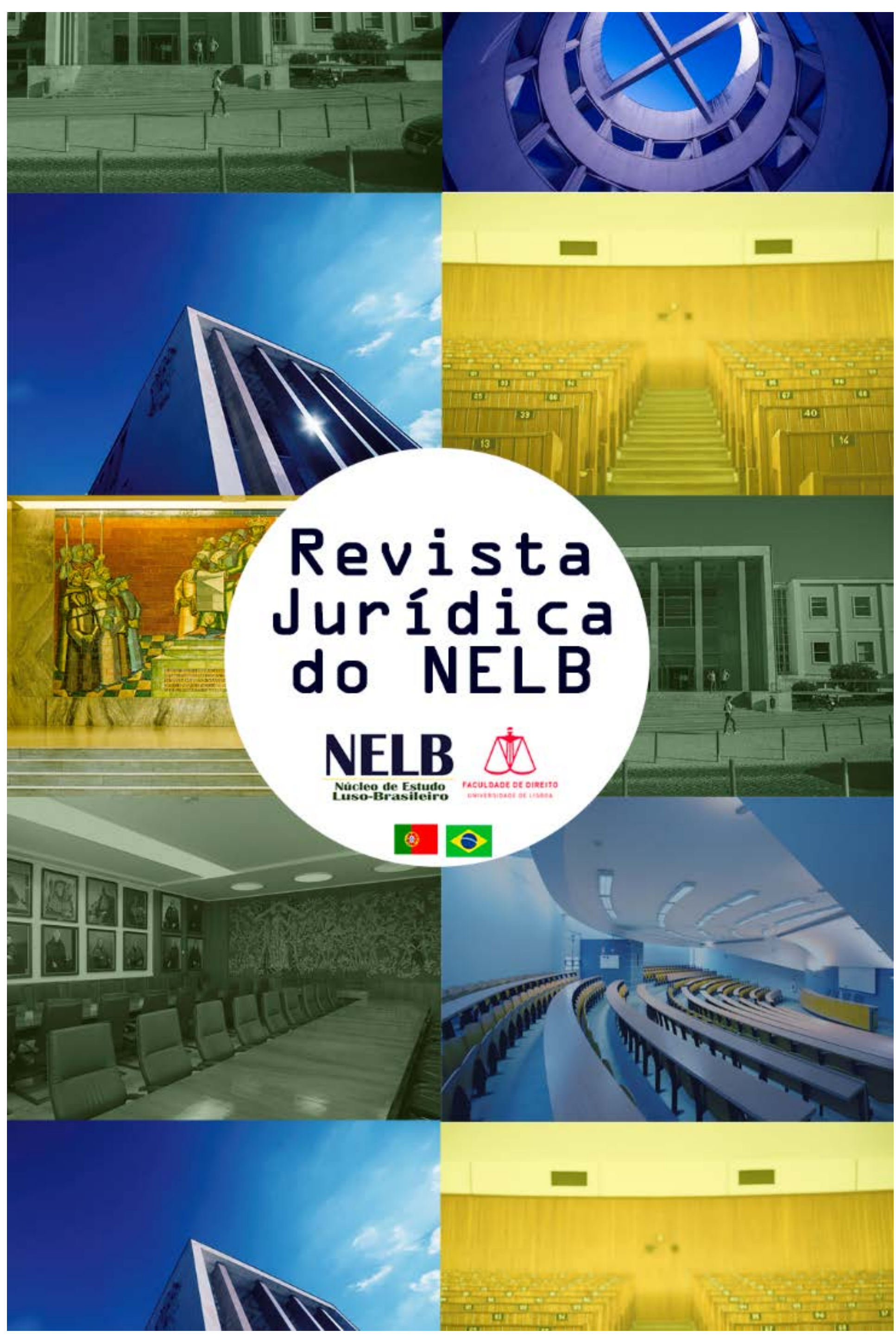




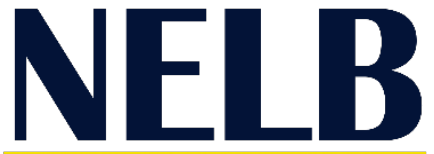

Núcleo de Estudo Luso-Brasileiro

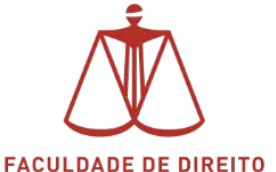

FACULDADE DE DIREITO

UNIVERSIDADE DE LISBOA

\section{REVISTA JURÍDICA DO NELB}

Primeira Edição - Ano 2018. 

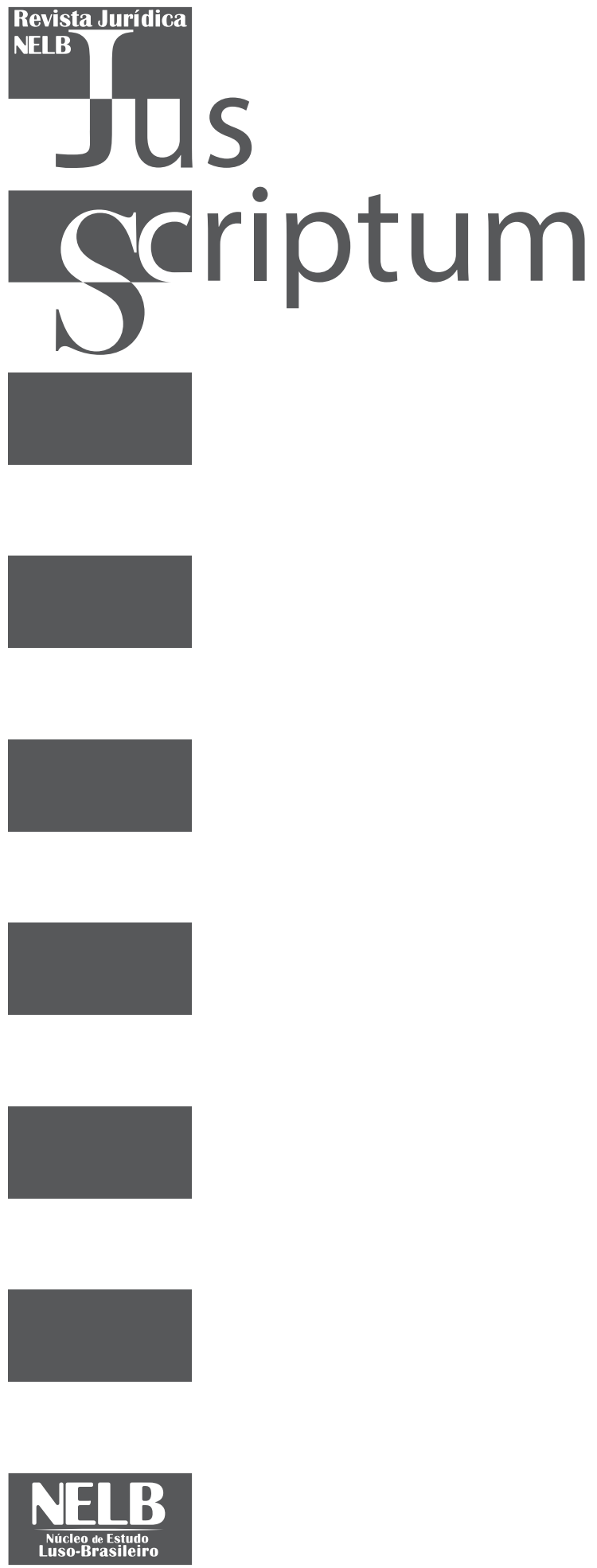


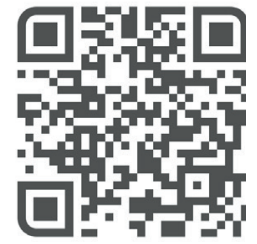

jusscriptum.pt

\section{REVISTA JURÍD|CA NÍCLET DE ESTUDO LUSD-BRASILEIRQ FACLLDADE DE DIREITQ DA ULISBDA \\ EDIÇÃO ESPECIAL DOS VOLUMES 1 A 5 Lisboa - Portugal \\ Periodicidade Trimestral ISSN 1645-9024}

Diretor da Revista - Editor-In-Chief Cláudio Cardona

Conselho Editorial - Editorial Board

André Brito, Presidente do NELB Cláudio Cardona, Diretor da JusScriptum Paulo Rodrigues, Diretor Científico do NELB Laura Viana, Diretora Científica interina do NELB Thiago Santos Rocha, Observador Externo

Conselho Científico - Scientific Advisory Board

Ana Rita Gil

Faculdade de Direito da Universidade de Lisboa

André Saddy

Faculdade de Direito da Universidade Federal Fluminense

Edvaldo Brito

Faculdade de Direito da Universidade Federal da Bahia

Eduardo Vera-Cruz Pinto

Faculdade de Direito da Universidade de Lisboa

Fernanda Martins

Universidade do Vale do Itajaí

Francisco Rezek

Francisco Resek Sociedade de Advogados

Janaina Matida

Faculdade de Direito da UniversidadeAlberto Hurtado

Lilian Márcia Balmant Emerique

Faculdade Nacional de Direito - UFRJ

Luciana Costa da Fonseca

Universidade Federal do Pará

\section{Corpo de Avaliadores - Review Board}

Camila Franco Henriques

Eduardo Alvares de Oliveira

Francine Pinto da Silva Joseph

Isaac Kofi Medeiros

J. Eduardo Amorim

José Antonio Cordeiro de Oliveira

Leonardo Bruno Pereira de Moraes
Maria Cristina Carmignani

Faculdade de Direito da Universidade de São Paulo

Maria João Estorninho

Faculdade de Direito da Universidade de Lisboa

Paula Rosado Pereira

Faculdade de Direito da Universidade de Lisboa

Paula Vaz Freire

Faculdade de Direito da Universidade de Lisboa

Pedro Romano Martinez

Faculdade de Direito da Universidade de Lisboa

Rute Saraiva

Faculdade de Direito da Universidade de Lisboa

Sergio Torres Teixeira

FaculdadedeDineitodaUniversidade Federal dePernambuco

Susana Antas Videira

Faculdade de Direito da Universidade de Lisboa

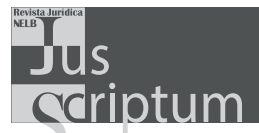

()
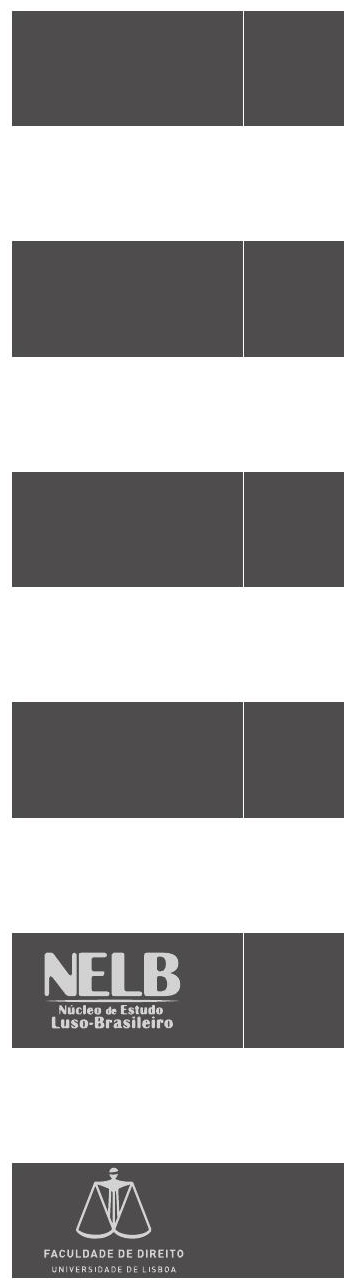

Marcelo Ribeiro de Oliveira Marcial Duarte de Sá Filho Maria Vitoria Galvan Momo Plínio Régis Baima de Almeida Rafael Vasconcellos deAraújo Pereira Rafaela Câmara Silva Silvia Gabriel Teixeira 


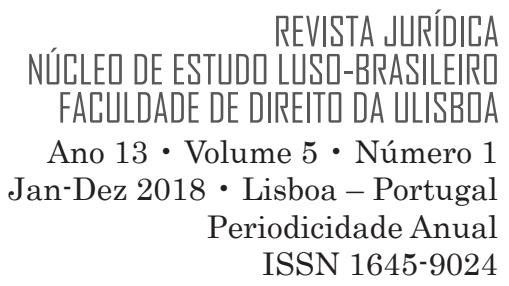

NELB - Núcleo de Estudo Luso-Brasileiro Fundado em 07/06/2001 Diretoria do Biênio 2017/18

Henrique Barbosa, Presidente Maria Eugênia M. Junqueira, Vice-Presidente Panmella Silva Cruz, Tesoureira Camila M. de Moura Vilela, Secretária-Geral Juliana de Freitas Dornelas, Diretora Científica Ana Carolina Agostinho A. Cruz, Diretora Científica João Pedro Leite Barros, Diretor Científico Elizabeth Lima, Diretora de Eventos

Alyne Andrade, Diretora de Eventos Carmille Leal do Amaral, Diretora de Eventos Felipe Pires Muniz de Brito, Diretor de Eventos Tatyana Barbosa, Diretora de Eventos Gabriel da Silva Ferreira, Diretor de Comunicação e Imagem

Lara Ferreira Andrade, Diretora de Licenciatura Deborah Silvério, Diretora de Licenciatura

Comissão de Redação: Alyne Andrade Ana Carolina Agosti Cruz Felipe Pires Muniz de Brito Henrique Bonatti Rego Barbosa João Pedro Leite Barros Juliana de Freitas Dornelas Maria Eugênia Junqueira
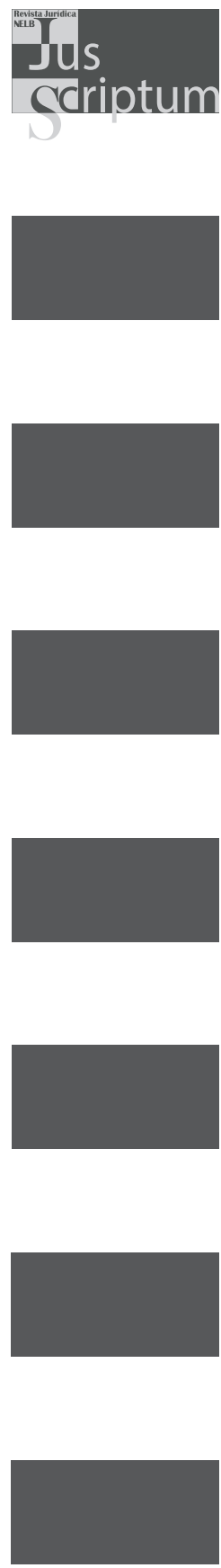


\title{
ENTRE ADESÃO PARCIAL E CRÍTICA AO POSITIVISMO JURÍDICO - A TEORIA E FILOSOFIA DO DIREITO EM TOBIAS BARRETO DE MENEZES.
}

\section{BETWEEN PARTIAL ADEHERENCE AND CRITICS OF LEGAL POSITIVISM - THE TEHORY AND PHILOSOPHY OF LAW IN TOBIAS BARRETO DE MENEZES}

\author{
Alberto de Moraes Papaléo Paes \\ Doutorando em Direito pela Universidade Federal do Pará (UFPA) \\ Mestre em Direito pela Universidade da Amazônia (UNAMA) \\ Graduado em Direito pela Universidade da Amazônia (UNAMA) \\ Professor Universitário na Universidade da Amazônia (UNAMA) \\ E na Faculdade Estácio de Sá - Pará (FAP-ESTACIO)
}

SUMÁRIO: 1. Introdução - Resgate de Tradição Jurídica Brasileira (Latino-americana). 2. Positivismo Jurídico - Qual positivismo? 2.1. O Dissenso entre Direito Positivo x Natural no período de 1800 à 1850. 3. Tobias Barreto de Menezes e a sua obra. 3.1. Adesão Parcial ao Positivismo. 3.2. Crítica aos Positivistas. 4. Conclusões. 5. Referências Bibliográficas.

RESUMO: O presente trabalho possui como objetivo principal o resgate da tradição brasileira através da rediscussão da importância da obra de Tobias Barreto de Menezes. Como a maior influência do movimento da conhecida Escola do Recife Tobias é responsável pela introdução do germanismo no Brasil e por ter sido um crítico do pensamento Ecletista Espiritualista. Nesse sentido, sua crítica a uma proposta de Direito Natural acusa uma adesão parcial ao positivismo, porém, em outro momento de sua produção ele começa a produzir uma crítica ao que se tornou o positivismo no Brasil. Há, portanto, uma linha muito tênue entre esses dois argumentos que parecem ser uma mudança paradoxal de posição, quando na verdade é a manutenção de uma mesma posição.

PALAVRAS-CHAVE: Positivismo; Tradição; Escola do Recife; Tobias Barreto.

ABSTRACT: The present work has as main objective the rescue of the Brazilian tradition through the rediscussion of the importance of the work of Tobias Barreto de Menezes. In this sense, his critique of a Natural Law proposal implies a partial adherence to positivism, but at another moment of his production he begins to produce a critique of what has become positivism in Brazil. There is a very thin line between these two arguments which seem to be a paradoxical change of position, when in fact it is the maintenance of the same position.

KEYWORDS: Legal Positivism; Tradition; Recife Shcool; Tobias Barreto.

\section{Introdução - Resgate de Tradição Jurídica Brasileira (Latino-americana).}

Não se pode olvidar que o argumento da necessidade de emancipação da filosofia latinoamericana rendeu (e tem rendido) alguns bons frutos para a noção de pós-colonialismo que se lançou na modernidade periférica. A filosofia dos países do centro não deixou de ser importante, ela meramente se tornou alvo de críticas como modelo/forma preconcebida de controle da cultura e do pensamento 
periférico. Conforme leciona o professor Enrique Dussel (1977) a filosofia ocidental se forma como um modo de controle da periferia pelo centro, desde os gregos, que eram escravocratas, aos filósofos americanos, que detém um monopólio econômico, a imagem do mundo se desenhou através desse domínio e dessa opressão do pensamento (pág. 08-21). O reconhecimento da identidade desse pensamento e sua autonomia é que acusa o maior dos "problemas" que a filosofia da libertação pretende resolver.

Em se falando de Brasil algumas ponderações preliminares precisam ser efetuadas. Após o "descobrimento" em 1500, Portugal vivia uma livre ascensão de uma Escolástica Tomista por conta da necessidade de garantia do conservadorismo português (PAIM, 1999, pág. 39-40). Isto retardou ao portugueses um estudo sério sobre a filosofia moderna que se desenvolveu até o século XIX. Dizemos isto, porque durante a revolução pombalina o ensino "normal" em Portugal fora sendo paulatinamente substituído pela nova "tradição" filosófica, menos divina e mais científica (PAIM, 1999, pág. 43-8), até que isto culminou com a imposição napoleônica de modificação da lei portuguesa e a eventual vinda da família real para o Brasil. O conservadorismo português alcança o Brasil com a instituição da chamada segunda escolástica portuguesa e neste quadro a filosofia brasileira começa a se desenvolver. Primeiramente como tomísita/platônica/aristotélica, passando por uma compreensão sobre as leituras neo-kantianas na França e dando um salto epistêmico pela inserção do germanismo no Brasil algum tempo depois ${ }^{1}$.

Por conta desta primeira influência da escolástica portuguesa, com a criação, durante o primeiro império, das faculdades de direito (1828) o conservadorismo dos colonos impôs ao pensamento brasileiro a observância e leniência de uma só doutrina filosófica que se preocupava com a relação da moral com a natureza humana a fim de justificar a manutenção de estudos escolásticos e do próprio império, chamavase ela de: Ecletismo Espiritualista. Fundado nas lições de Biran e Cousin, estudado por Salustiano Pedrosa e Gonçalves de Magalhães, ela se tornou a primeira escola filosófica bem fundada no Brasil (PAIM, 1999, pág. 57-9). Desta narrativa decorre a fixação de um marco de pensamento filosófico como imposição da vontade colonial portuguesa para o povo brasileiro.

A tímida noção de liberalismo e emancipação política que insurge no Brasil, até por volta do ano de 1891 com a promulgação da primeira Constituição Republicana, é uma noção que vem acompanhada de uma extensa e profunda crítica ao modelo do pensamento imposto pela coroa portuguesa. Tal crítica será encabeçada por professores e intelectuais que protestavam a superação do Ecletismo Espiritualista. Precisamente quando Sílvio Romero decreta a morte da metafísica (1875) o movimento disperso começa

1 Datam-se de 1804 os primeiros estudos relativos à obra de Kant no Brasil, cerca de oitenta anos depois de seu amplo desenvolvimento da Europa e cerca de quarenta anos antes das primeiras publicações de Tobias Barreto. A chegada da filosofia alemã no Brasil antecede o movimento germanista encabeçado por Tobias através da Escola do Recife. 
a ganhar corpo e se sobressai a figura de Tobias Barreto de Menezes (PAIM, 1999, pág. 101). De natureza um crítico áspero, sarcástico e feroz, Tobias se tornou o grande expoente do movimento recifense ${ }^{2}$. Nas palavras de Luiz Antônio Barreto (1994) biógrafo de Tobias; “Tobias Barreto é um sedutor. Seduziu jovens nordestinos, alunos da Faculdade de Direito do Recife, destronando os velhos conceitos embolorados nos compêndios sacralizados" (pág. 04). E segue finalizando sua introdução à biografia de Tobias com extrema felicidade "Somente os que não conhecem a obra tobiática, e nem o contexto que a gerou, passam ao largo da figura genial do poeta filósofo, um dos poucos a fazer do Brasil o objeto de suas preocupações e dos seus estudos" (MENEZES, 1994, pág. 04).

Durante 1839 até o ano de 1889 (50 anos) Tobias viveu e construiu seu legado. Hoje, por grande sorte, existem muitas obras que conseguiram ser resgatas, algumas caíram no domínio público e podem ser disponibilizadas gratuitamente para os pesquisadores interessados. Infelizmente, a figura de Tobias foi sendo paulatinamente substituída nos últimos 120 anos por leituras de Kelsen, Austin, Hart, Dworkin, Alexy, Posner, Waluchow, Raz, etc ${ }^{3}$. É pouco o interesse sobre a pesquisa a respeito da obra de Tobias Barreto que, inclusive, era estudado e celebrado na Alemanha em seu tempo e continua a ser pelos alemães ainda hoje. O resgate do pensamento jurídico na obra de Tobias é essencial para reconhecer os problemas do nosso tempo. Não só isso, ele se torna crucial para começar a compreender essa identidade brasileira na forma daquilo que se conhece a partir de Gadamer (1999) como sendo a "Tradição". Em poucas palavras (se é que isso é possível) a história da ontologia da identidade jurídica do Brasil. Uma sucessão de fatos que narram uma história, mas um fio que fora rompido em algum lugar na história recente e que precisa ser reatado pela compreensão da historicidade do Dasein.

No presente trabalho pretendemos, por força do exposto até aqui, proceder um amplo resgate da importância da obra tobiática para o Direito Brasileiro. Portanto, nossa perspectiva é historiográfica (porque preocupada em uma historiografia crítica), de filosofia do direito (porque preocupada nas justificativas e pressupostos da epistemologia jurídica), e de teoria do direito (porque preocupada com o método do direito). Numa primeira análise, por conta da perspectiva histórica, passamos a expor o que é o problema central da presente pesquisa. Em alguns trabalhos sobre Tobias suas produções são divididas em "fases" pelas quais evolui seu pensamento. Num primeiro momento, em suas primeiras publicações, Tobias é identificado como um crítico do jusnaturalismo, portanto, demonstrando uma aderência parcial ao Positivismo (MERCADANTE;PAIM;1977). Noutra "fase" de sua produção bibliográfica, Tobias é

2 Ressalte-se que àquela altura existiam apenas duas faculdades de direito no Brasil: a) a Faculdade de Direito do Largo de São Francisco (Hoje a USP) e; a Faculdade de Direito de Recife. Curiosamente, ambas criadas em grandes centros de ensino e pesquisa de fundo escolástico.

3 O grande detalhe, e talvez esse passe realmente despercebido por quase todos, é o fato de que dentro da discussão moderna sobre o conceito e validade do direito, o professor Eugênio Bulygin tem se tornado figura importantíssima como expoente do pensamento latino-americano e, portanto, merece toda a reverência. 
catalogado como um crítico do positivismo jurídico, ou melhor, o que o Brasil convencionou em chamar de positivismo (MERCADANTE; PAIM; 1977). Desse modo, surge a grande dúvida: como é possível aderir (ainda que parcialmente) ao positivismo e, ao mesmo tempo (ainda que em momentos históricos diferentes) criticá-lo? Por uma estrutura da analítica aristotélica poderíamos fazer a seguinte formulação:

\section{a) Pressupostos da Crítica Tobiática:}

a1) Por discordâncias formais:

i) argumentos empíricos ${ }^{4}$;

ii) argumentos epistêmicos ${ }^{5}$;

iii) argumentos metodológicos ${ }^{6}$;

a2) Por discordâncias materiais:

i) argumentos filosóficos (lato sensu) ${ }^{7}$;

ii) argumentos teóricos e práticos (lato sensu) ${ }^{8}$.

$4 \quad$ A análise empírica reconstitui a afirmação da escola do Empirismo Britânico onde o desenho do mundo se dá pela construção da experiência. Desse modo, um exemplo claro se daria a partir de um conceito de direito que fosse integralmente pautado em sua prática, como no caso do Realismo Jurídico.

5 A análise feita por meio de uma crítica epistêmica diz respeito à Teoria Geral do Conhecimento e da justificativa de suas formas. Um exemplo desta proposição diz respeito à base da crítica positivista ao jusnaturalismo, negando a metafísica clássica e instituindo um alicerce onde a teoria pode ser construída.

6 Os argumentos metodológicos consistem em considerações voltadas para o método que apoia a justificativa de determinada posição dentro de um esquema científico. Um exemplo é a Teoria do Direito em Kelsen (2006), que preocupa-se, eminentemente, com um método adequado para compreensão da qualidade jurídica como relativa à "norma jurídica", sua validade e sua vinculação com o "dever-ser" (sollen). Note-se que um pressuposto da crítica metodológica é a sua automática e natural vinculação com uma crítica epistemológica, porém, ambas possuem objetivos diferentes.

7 Argumentar sobre a existência de uma crítica filosófica é, de pronto, estabelecer um conceito semântico do que se pretende por filosofia. Dividimos o termo em duas possibilidades interpretativas: a) lato sensu e; b) stricto sensu. Por filosofia lato sensu referimo-nos a capacidade de inquietação com a realidade, uma "postura" por assim dizer. Aquele que filosofa desse modo pode ser levado à utilização de argumentos fenomenológicos, ontológicos, clássicos, modernos, vinculado a uma, ou, algumas tradições, entre outras coisas. Aquele que apoia sua crítica em uma visão parcial do seu objeto trabalha a filosofia a partir de uma perspectiva stricto sensu. Nesta estrutura pretendemos utilizar o primeiro conceito.

8 Teoria e Prática são um binômio que somados à pesquisa se tornam o trivium da ciência jurídica e da academia moderna. Utilizamos esta perspectiva pela própria natureza do direito, como sustenta Hart (2012): não há pergunta mais feita na modernidade do que "o que é o direito?" (pág. 8). Esta característica do Direito importa em questões materiais importantes sobre os seus diversos conceitos e todos são cogitações que comungam sua teorização e sua prática. 
A Crítica por discordâncias formais baseada em argumentos empíricos não denota nem adesão nem rompimento do ponto de vista científico, pois, pode ser categorizada simplesmente como um préconceito no sentido gadameriano (portanto, um vício interpretativo quando ilegítimo). De outra sorte, quando a discordância formal é baseada em argumentos epistêmicos ou metodológicos a questão é posta de modo dialógico: ou há adesão, ou há rompimento. Não há possibilidade de alargamento interpretativo para "meios termos". Apenas a crítica baseada em discordâncias materiais suscitaria a possibilidade de uma adesão parcial, por motivos filosóficos ou teóricos/práticos. A questão é saber em qual grau qualitativo realmente a obra de Tobias foi capaz de fornecer uma crítica e qual a sua vinculação às possibilidades críticas de acordo com o esquema supra. Podemos concluir, desse modo, a possibilidade de comprovação de algumas hipóteses para o presente trabalho:

h1) houve adesão parcial ao positivismo jurídico de modo a viabilizar uma futura crítica, o que significa:

i) criação de uma nova teoria do direito ou;

ii) aprimoramento de uma teoria já existente;

h2) não houve adesão parcial e a crítica é:

i) uma quebra de sincretismo;

ii) uma mudança de percepção;

iii) uma possibilidade de retorno.

Ainda, assim, como questão incidente ao proposto, torna-se viável, por essa estrutura lógica, presumir que a Teoria Crítica em Tobias não tinha um cunho meramente negativo, ela não visava somente apontar os erros e as opacidades nos discursos adversários. Ela possuía um caráter pedagógico, na medida em que construía algo sólido por cima do que derrubava. Comprovada, realmente a hipótese "h1" e descartando-se sua variante "ii", estamos diante de território inexplorado que é a percepção da existência de uma Teoria do Direito autenticamente brasileira. Não poderíamos aqui falar de descobrimento, pois ela já faz parte (ainda que inconscientemente) da Tradição; mas sim de reconhecimento de uma tal teoria. 
Para atingir estes objetivos, pretendemos, antes de mais nada, desenvolver um pequeno histórico acerca da perspectiva positivista em face da jusnaturalista para compreender, essencialmente, sua recepção no Brasil. Logo após, tentaremos aumentar qualitativamente tal argumento, inserindo o contexto do dissenso entre Jesuítas e Pombalinos no Brasil e a influência deste debate na educação. Logo após, passaremos à análise dos escritos e obras de Tobias Barreto com a finalidade e o escopo principal de analisar o percurso da construção de seu pensamento e responder a instigação principal do presente trabalho, para, somente, então, passar a proferir nossas conclusões.

\section{Positivismo Jurídico - Qual positivismo?}

“E' mister bater, bater cem vezes, e cem vezes repetir: o direito não é filho do céo, é simplesmente um phenomeno historico, um producto cultural da humanidade. Serpens nisi serpentem comederit, non fit draco, a serpe que não devora a serpe, não se faz dragão; a força que não vence a força, não se faz direito; o direito é a força que matou a própria força." (MENEZES, 1923, pág. 175).

Conhecer o passado. Não de maneira vaga, imprecisa ou, de outra sorte, pontualmente e puramente através de documentos e simples fatos, constatações. Compreender o passado. Não de maneira leviana tentando fazer conexões que não existem ou tentar provar o improvável. Neste tópico a missão mais peculiar é problematizar a necessidade da pesquisa histórica que entrelaça o conhecimento do homem (enquanto homem) e de uma das ferramentas mais peculiares da ciência jurídica: o Positivismo Jurídico. A redundância pode (e muitas vezes vai) se tornar necessária quando se utilizar o termo "jurídico", contudo, tentar-se-á, a todo custo, sistematizar o propósito da descoberta da raiz de tal ferramenta em uma redução metodológica a partir de um contexto do geral para o específico. Não podem haver aqui equívocos capazes de contaminar a construção do fio condutor da história do positivismo jurídico, ou, do contexto em que se forma a "Escola do Recife". Portanto, far-se-á um recorte geral a partir da monografia sobre Positivismo Jurídico realizada por Norberto Bobbio (1995), sendo complementada (no que couber) com outras bibliografias mais específicas de um, ou, outro tema que se achar salutar, para que se possa chegar até o problema central deste trabalho.

O ponto de partida desta investigação é a exata compreensão do que significa (ou pelo menos o que vem significando) o emprego do termo "positivismo" ao longo da evolução da ciência do Direito. Na verdade, "a expressão 'positivismo jurídico' não deriva daquela de 'positivismo' em sentido filosófico" (BOBBIO, 1995, pág. 15), sendo, usualmente, o primeiro colocado como contradição necessária do Direito Natural. A questão sobre a natureza destes dois direitos não é o objetivo principal desta exposição, mas 
merece atenção a revisão histórica feita por Bobbio (1995) sobre o tema como uma tentativa de indicar o contexto em que (por exemplo) os Gregos discutiam a thésis e a physis; ou como os Romanos discutiam o jus civile do jus gentium ${ }^{9}$. Tal iniciativa pode ser recortada de modo metodológico para que seja possível tornar mais claro o objeto principal.

De certo modo ao se debruçar sobre a questão histórica o homem se torna capaz de observar os detalhes e as circunstâncias a respeito das quais uma determinada coisa acontece, se funda, ou melhor, se origina. Ao atestar a questão da dialogicidade entre o Direito Natural e o Positivo na história, Bobbio (1995) percebe que em algum momento o chamado Direito Positivo ganha uma proporção maior que o Natural ${ }^{10}$ (pág. 26). A averiguação das circunstâncias determinantes para tal viragem demonstra que a validade das ordens jurídicas, até a Idade Média, passava meramente por um critério de legitimidade social "o direito aí se apresentava como um fenômeno social, produzido não pelo Estado, mas pela sociedade civil” (BOBBIO, 1995, pág. 27). Daí porque a estrutura monista é adotada inicialmente como forma de validar o direito como num processo de monopolização da produção jurídica ${ }^{11}$ (entenda-se aqui tanto a criação de uma lei, quanto a aplicação desta lei pelo Estado/Juiz).

A grande questão então, se torna: como o cenário da Idade Média consegue alcançar e influenciar os caminhos da modernidade no Direito? Bem, colocando os Romanos ao lado dos Gregos na antiguidade é possível perceber que, assim como os primeiros se influenciam nos segundos, há uma diversa gama de correlações entre Roma e os acontecimentos supervenientes na história do homem. Como exemplo é possível citar a título de precedentes do positivismo jurídico as compilações feitas por Justiniano como

9 Neste sentido cabe lembrar que a intenção dos cinco primeiros capítulos da obra "O Positivismo Jurídico" de Norberto Bobbio (1995) é puramente histórica. Portanto a revisão histórica de Bobbio (1995) tenta demonstrar em que circunstâncias se desenvolve o chamado Positivismo Jurídico, sendo, desse modo, a primeira parte/sessão do mesmo dedicada somente a questões históricas. Muito por oportuno, ao destacar na antiguidade a diferenciação dessas teses, pretende o autor italiano demonstrar uma coisa: que a natureza das discussões da modernidade reside nos problemas dos antepassados. Melhor explicado, o direito positivo como se conhece hoje só é capaz de existir (do modo como existe) a partir da compreensão dos problemas apresentados pelos Gregos e pelos Romanos. Tais problemas foram solucionados e a teoria do Direito Positivo prosperou em alguns países, todavia, seu germe reside (historicamente) na antiguidade (BOBBIO, 1995, pág. 15-122).

10 É importante salientar que em que pesem os diversos estudos escolásticos sobre a afirmação do Direito Natural como um mandamento divino (Jus naturale est quod in Lege et in Evangelio continetur) "o direito positivo passa a ser considerado como direito em sentido próprio (...) O direito positivo é direito, e o direito natural não é direito" (BOBBIO, 1995, pág. 26). E por essa razão a historiografia do Positivismo se torna salutar para o autor italiano. De outra sorte, não se está aqui a negar a existência do Direto Natural na modernidade, apenas aponta-se para a direção em que o estudo, agora chamado de científico (divorciado da compreensão teológica), toma na modernidade e como que isso influencia diretamente a Ciência do Direito (positiva ou negativamente).

11 Vale a ressalva de que tal processo funciona tanto para criar o direito de modo direito (sem intermediários), através da lei, ou, indiretamente, “através do reconhecimento e controle das normas de formação consuetudinárias” (BOBBIO, 1995, pág. 27). Esta constatação leva diretamente ao contexto de criação de obras de defesa ao positivismo jurídico em suas mais diversas formas de apresentação na modernidade, tais como as de Austin (1954), Hart (2012), Kelsen (2006), Alexy (2011a), Waluchow (2002), Himma (2002), Marmor (2014), dentre outros. 
uma forma primitiva de centralização/monopolização da produção jurídica (quod principi placuit legis habet vigorem / solus principis facere leges) (BOBBIO, 1995, pág. 30). Merece destaque a assertiva de que

\begin{abstract}
"O direito romano se eclipsou na Europa durante a alta Idade Média, substituído pelos costumes locais e pelo novo direito próprio das populações germânicas (ou bárbaras). Mas depois do obumbramento ocorrido em tal período - obumbramento comum, de resto, àquele de toda a cultura - ressurgiu no primeiro milênio com o aparecimento da Escola jurídica de Bolonha e difundiu-se não apenas nos territórios sobre os quais já se havia estendido o Império Romano, mas também sobre outros territórios jamais dominados por este; sobretudo na Alemanha, onde ocorreu no início da Idade Moderna o fenômeno da 'recepção', graças ao qual o direito romano penetrou profundamente na sociedade alemã". (BOBBIO, 1995, pág. 30).
\end{abstract}

A raiz do direito que passa a ser utilizada começa a levar em conta a ratio scripta como um conjunto de regras que se funda racionalmente na Jurisrecht (razão jurídica). Este fundamento de validade começa a alcançar a Europa Ocidental e dentre os diversos países que se influenciam pela ideia de direito (romana) é possível encontrar: Alemanha, Itália, Holanda e França (dentre outros). Entretanto, é na Alemanha que se vai proceder a uma dura crítica ao Direito Natural nas obras de Savigny e Gustavo Hugo (Lehbuch des Naturrecht als einer Philosophie des positiven Recht) com o desenvolvimento da chamada "escola histórica" (Historischen Rechtsschule). Segundo José D’Assunção Barros (2013), o historicismo alemão "deverá ser entendido em sua relação direta com o contexto de afirmação dos Estados-Nacionais" (pág. 392), daí segue-se uma visão política do movimento que teria como necessidade precípua a afirmação da vontade do estado. De outra sorte, Helmut Coing ${ }^{12}$ (1977) assevera que existem pelo menos três ideias fundamentais: a) a fórmula do domínio ou controle pelo direito através do espírito do povo (Beherrschung des Recht durch den Volksgeist); b) a compreensão de uma evolução orgânica de determinadas ideias dentro do espírito do povo; e c) a compreensão histórica do direito é (ao mesmo tempo) o fundamento da compreensão do direito vigente e de sua dogmática (pág. 47-8).

A resinificação do Direito Natural em face à necessidade de uma tutela exclusiva do Estado da produção jurídica fez com que diversos autores se debruçassem sobre o estudo do conceito do Direito Positivo. Nesta seara, então, não só na Alemanha e nos estudos de Savigny e Gustavo Hugo encontravam-

12 Num dos capítulos da obra de Maria del Refúgio González, o professor Helmut Coing aborda o que ele vem a denominar de actitudes metodológicas em la historia del derecho alemán, para tanto lança mão de uma divisão tópica e analítica para diferenciar três ideias principais que acabam por fundamentar o historicismo alemão, e três consequências fundamentais. Dentre elas é possível citar a título de esclarecimento "la idea segun la cual el derecho era expresión del espiritu del pueblo, o de la cultura nacional, condujo a periodificar el objeto historia del derecho al margen de determinadas épocas en función del origen nacional del derecho alemán o germánico” (COING, 1977, pág. 48). 
se notas sobre a compreensão do Direito Positivo. Na França o movimento lluminista deixa o cenário adequado para a criação do Código de Napoleão como um marco histórico do desenvolvimento dos estudos sobre o direito codificado. Nasce, neste contexto, a escola da exegese e tempos depois a chamada escola científica ${ }^{13}$. Na Inglaterra os trabalhos de Bentham e Austin começam a ganhar repercussão por estabelecerem as bases do legal positivism, seja num conceito utilitarista da divisão de maior felicidade para o maior número, ou, numa visão de aproximação entre o historicismo alemão e o utilitarismo inglês. Levando-se em conta um determinado país, nação, tempo, ou momento, a discussão acerca do positivismo alcança a modernidade através dos estudos de determinados autores e da atuação deles na demarcação de seus limites. De modo que surge a necessidade de arquitetar um esqueleto para esse Direito Positivo e para esse chamado Positivismo Jurídico. É possível sintetizar tais limites do seguinte forma:

a) Ato regulatório da fala (ou enunciado normativo racional) que tem por objeto a ordenação da conduta humana;

b) Posto pelo Estado através de um processo democrático de representação do cidadão, diretamente, ou, através de representantes ${ }^{14}$;

c) Valida-se numa cadeia hierárquica que compreende normas de diversos escalões onde a de maior escalão valida a de menor (entendendo-se que a constituição sendo o âmbito de validade de todo o ordenamento validade numa norma hipotética fundamental ou, grundnorm);

d) Os enunciados normativos podem ser intencionalmente ou não-intencionalmente indeterminados cabendo ao Estado/Juiz o papel de preenchimento das lacunas decorrentes de tal indeterminação;

e) Não havendo lei sob a qual o Estado/Juiz possa utilizar-se para resolver um determinado litígio, deve ele se utilizar de outras fontes do direito (costumes, analogia, jurisprudência, princípios gerais do direito, doutrina e equidade);

Em linhas gerais estes são alguns dos aspectos mais conhecidos e incontroversos sobre a descrição do positivismo jurídico e sua historiologia. Pode ser que, a princípio, pelo fato de não ser o objeto principal desta pesquisa a narrativa e as asserções realizadas até o presente momento pareçam vagas, mas, como exposto alhures, primando por uma objetividade e clareza o argumento que se tentou construir até aqui pode ser resumido na seguinte afirmativa: para entender o direito na modernidade é necessário compreender sua origem histórica. Fica bem claro então, porque Bobbio (1995) se preocupou em descrever na primeira parte de sua obra uma historiografia do direito positivo. Contudo, essa compreensão não significa, automaticamente, a descoberta de uma ferramenta capaz de resolver os problemas jurídicos da modernidade. Dentre tais problemas é possível citar: a) a autonomia da norma

13 Sem esquecer-se, é claro, da Bergrifjurisprudenz (a Escola da Jurisprudência dos conceitos) como uma provocação do próprio historicismo alemão.

14 Ressaltem-se, ainda na modernidade, a existência de modelos jurídicos autoritários no qual a participação popular é diminuta ou inexistente, como são os casos de Cuba e da Coréia do Norte. 
jurídica; b) a construção democrática dos enunciados normativos; c) a interpretação jurídica; d) o papel da globalização nas soberanias estatais; entre diversos outros problemas. Talvez o maior deles esteja num dos fatos mais controversos sobre a natureza do Direito Positivo: sua relação com a Moral ${ }^{15}$.

Neste quesito, então, a exata dimensão da chamada "complexidade" da modernidade (como uma questão de raiz puramente epistemológica) acusa os erros da dogmática jurídica nacional e internacional. Os problemas do direito não são mais problemas de solução única e exclusivamente jurídicos. De modo que o paradigma insurgente da grande crise de falta de respostas (efetivas) para os gritos da humanidade tem se apoiado na interdisciplinaridade, no caráter de complementaridade das ciências e vem de modo ainda paulatino, se delimitando sob a alcunha de "sistêmico". A compreensão histórica anterior (a exemplo da escola histórica) é de certo modo substituída porque os métodos passam a exprimir objetivos diferentes. Enquanto que os historicistas estavam preocupados em desvendar a natureza do direito através de uma compreensão da expressão do volksgeist, hoje, os estudos históricos estão preocupados em apontar as falhas e os momentos determinantes que contribuíram para que, por exemplo, o "problema" da desigualdade possa vir a existir no mundo a partir da (não) atuação jurídica.

Conforme leciona o professor Antônio Junqueira de Azevedo (1993) o Direito Português se influencia no humanismo jurídico francês na tentativa de depuração dos textos jurídicos perfazendo uma libertação de um descritivismo (excesso de comentários) e se socorrendo de uma crítica histórica a fim de desvendar o significado original dos enunciados romanos (Corpus Juris Civilis) (pág. 184). Desse modo os cinco livros das chamadas Ordenações Manuelinas constituíram a base jurídico positiva para a compreensão do Direito e essa experiência portuguesa acusa o transporte, não só dos costumes, cultura e práticas, mas, também da mentalidade jurídica que, séculos depois, seria levada ao Brasil. Essa tradição que vem a ser levada ao Brasil impõe (desde já) uma adoção histórica pelo sistema germano românico, mas não só isso, a averiguação de que, diferentemente, do que ocorre em outras tradições, o direito brasileiro não se funda em conquistas e evoluções históricas incorporadas à experiência do povo brasileiro (como no caso dos Gregos e dos Romanos), mas sim de uma transposição de modelos da metrópole para a colônia (WOLKMER, 2006, pág. 295).

Essa concepção deve ser colocada pari passu ao fato de que a religião da coroa portuguesa também chega no território brasileiro como um modelo legado à tradição. Disto segue-se a constatação

15 Sobre o tema é importante citar os estudos clássicos de Kelsen (2006) quando aborda a ideia de separação entre Direito e Moral. Outro autor clássico que trabalha a questão é Hart (2012) que no posfácio de seu conceito de Direito responde às críticas de Dworkin (1978) fornecendo a compreensão acerca da perspectiva do "participante" e do “observador” na descrição do coneito de direito. A relação entre Direito e Moral parte da premissa de que a validade social do direito através da aceitação da sociedade é o que importa para a descrição da experiência jurídica. Modernamente citam-se os trabalhos de Paulson (2011), Waluchow (2002), Himma (2002) e Alexy (2011a) que falam sobre a concepção de um positivismo inclusivo, ou, não-positivismo inclusivo. 
de que os grandes centros de ensino no Brasil serão construídos com base nos ensinamentos neotomistas e neoaristotélicos como forma de uma escolástica já densamente debatida e construída ao longo de toda a Idade Média. Este cenário, que até parece conflitar, é o contexto do Direito no Brasil Colônia. Em tal modelo que preceitua, dentre outras coisas: a) uma forma escrita de conhecimento e reprodução do direito; b) uma forma escolástica de explicação da experiência humana; e c) uma necessidade de fornecer uma explicação para interpretação, aplicação e discussão das questões jurídicas através de uma filosofia crítica; é que o Direito começa a caminhar sobre as terras brasileiras.

Nesse momento ainda seria muito perigoso se dizer que exista uma justificativa formal jurídico positiva para explicação do conceito de Direito. Seria mais correto afirmar que, mesmo depois da criação das primeiras faculdades de Direito no Brasil o pensamento tipicamente acadêmico já residia na doutrina do chamado ecletismo espiritualista de Biran e Cousin, defendidos por grandes expoentes brasileiros como Salustiano Pedrosa e Gonçalves de Magalhães (PAIM, 1999, pág. 57). A corrente do ecletismo espiritualista como paradigma de pensamento incluí dentro de suas cogitações a metafísica na forma de questionamento à Moral, à Ética, e uma menção à explicação às ciências da natureza por métodos que afastam da compreensão uma racionalidade exclusivamente cartesiana de pensamento (PAIM, 1999, pág. 60). Ao fazê-lo, o ecletismo acaba por distanciar-se dos rigores metódicos impostos pela doutrina do positivismo que já vinha se formando durante o século XVIII, com os trabalhos de Savigny e Gustavo Hugo em reação à experiência com o Direito Natural.

Se torna, então, necessário justificar a validade científica do questionamento jurídico no Brasil e, se tomado por base o argumento epistêmico do ecletismo espiritualista, o Direito se elevaria ao quinhão de uma Ciência filosófico política social (etc.) e tantos outros quantos adjetivos pudessem ser alocados na explicação dessa experimentação. Somente após 31 de agosto de 1826 (dois anos depois da outorga da Carta Império por Dom Pedro) é que, na Faculdade de Direito de Pernambuco nasce uma crítica ao modelo tradicional de pensamento brasileiro dentro da conhecida "Escola do Recife"(PAIM, 1997, pág. 16). Desse modo, a crítica ao ecletismo espiritualista se transforma no primeiro ciclo de defesa de um positivismo científico dentro do direito, um raciocínio metódico que visa excluir do debate jurídico a gnose da natureza do direito. Esse tipo de argumentação e esse tipo de pensamento vai ser encontrado com maior frequência na obra de Tobias Barreto de Menezes, um dos grandes expoentes da Escola do Recife.

O que está se narrar no presente tópico não é uma tentativa de construção histórica do positivismo clássico, de transporte da tradição romana para a experiência brasileira, mas sim demonstrar o seguinte: se os conceitos de reconstrução e reintegração do sentido original do Sein estão diretamente ligados à compreensão histórica do objeto, então, esse contexto exprime o modo de ser do dasein, e a tradição jurídica que conceitua e entende a expressão "Positivismo Jurídico" no Brasil reputa a estes 
eventos a natureza do Direito ela própria. Em conclusão, a pesquisa bibliográfica relativa à obra de Tobias Barreto de Menezes se torna de extrema importância para o objetivo desta pesquisa. Outra importante constatação é o fato de que não havia, ainda, uma concepção de que a Academia deveria funcionar como um centro de produção e reprodução do conhecimento. O título de bacharel era visto por sua oportunidade de ascensão a cargos políticos, daí que a retórica e o embate se tornaram figuras que definiram o chamado bacharelismo no Brasil (PAIM, 1999, pág. 80). Este é o cenário em que a dimensão do positivismo encontra guarida para começar a ser discutido no Brasil.

\subsection{O Dissenso entre Direito Positivo x Natural no período de 1800 à 1850.}

Mcinerny (2006) define Direito Natural como "the first inescpable judgements human person makes as to what is good or evil in their actions" (pág. XI). Tal definição necessita de uma alocação temporal sobre o que foi o Direito Natural desde seu nascedouro, inclusive quando o assunto é a delimitação do positivismo jurídico alguns autores reconhecem a interdependência do conceito de Direito Natural e Direito Positivo (BOBBIO, 1995, pág. 15). Reputa-se a Aristóteles a fundação de um Direito baseado na natureza das coisas. Para Bobbio (1995) em sua Ética a Nicômaco, Aristóteles já começa a discriminar algumas caraterísticas do Direito Natural a partir da aceitação da sua validade universal e sobre o conteúdo das ações que são disciplinadas (pág. 16-7). O enfrentamento da questão sobre as origens e a validade do Direito Natural somente consegue ser discutido com clareza e precisão durante a Idade Média, quando se começa a divulgar a ideia de que "o direito natural não é posto por essses [homens], mas por algo (ou alguém) que está além desses, como a natureza (ou o próprio Deus)" (BOBBIO, 1995, pág. 19).

Coube, porém, a São Tomás de Aquino a missão de capitanear uma escola inteira de seguidores sob a bandeira do Direito Natural. Na Summa Theologica (I, a II. ae, q.90), o angélico doutor se reporta a categorias de leis, exprimindo que a razão e a sabedoria divina seriam o fundamento de validade da lei natural como uma parte (partícula) da Lex Aeternae, legando, desse modo à lei humana o reconhecimendo de sua validade somente quando comparada metricamente à conduta (ou juízo moral) exigido pela lei divina (BOBBIO, 1995, pág. 20). Não muito obstante, percebe-se que Aquino não se reporta a um Direito Divino, pois Deus é a fonte de toda sabedoria entrementes não poderia ser equiparado a um homem e, não muito raro, apesar de ficar perceptível a diferença entre lei natural e direito natural, Aquino por vezes as utiliza como sinônimos (MOURA, 2004, pág. 35). Em resumo, a diferença estaria alocada na concepção de lei enquanto instrumento ordenador da conduta humana e direito enquanto uma faculdade no ato da tomada de uma ação (ou inação) (MOURA, 2004, pág. 32). Neste sentido, a filosofia naturalista é revestida de uma capacidade de discussão e resolução de problemas éticos/morais, portanto 
presumindo a existência de uma filosofia moral como seu fundamento (que em essência provem de um "ser" suprahumano).

Este tipo de pensamento dominou todo o período da Idade Média. Os modelos políticos (centralizadores) utilizaram a ideia de um Direito Natural como argumento de autoridade para justificar a existência de governos Absolutistas (BOBBIO, 1995, pág. 35). Isto levou a uma necessidade de desconstrução de tal argumento, o que culminou, em última ratio na revolução burguesa, no lluminismo e no renascentismo (inclua-se aqui também a figura do humanismo). O Mito do Direito Natural é criado como uma forma de redução epistêmica do jusnaturalismo e neste cenário decaem os adpetos do Direito Natural. Neste diapasão argumenta Paim (1999) que os Jesuítas lograram êxito em isolar os protugueses do resto da Europa quando instituíram a Contra-Reforma ${ }^{16}$ (pág. 39) e o fizeram através de uma completa alienação do método dos "saberes da natureza" (método científico). Este movimento ficou conhecido como "Segunda Escolastica Portuguesa" (PAIM, 1999, pág. 39).

Este período da história das ideias no Brasil será estudado por nós da seguinte maneira: a) primeiro tentaremos descrever os reflexos práticos da filosofia tomista na cultura brasileira a partir da Segunda Escolásica; logo após, b) os reflexos práticos da opção do Primeiro Reinado pela utilização da filosofia Eclética Espiritualista de Biran e Cousin como filosofia oficial do Império Brasileiro. O Objetivo do primeiro tópico é o fornecimento de um retrato da realidade da filosofia naturalista no Brasil, enquanto que o do segundo é, simplesmente, o de contextualizar os debates que se seguiram entre os adpetos da versão eclética de naturalismo e os positivistas que surgem em meados do século XIX no Brasil.

Reconstruindo uma biobibliografia do período em questão (séc. XVII até meados do séc. XVIII), no Brasil os centros urbanos que se encarregaram de comportar certa vida intelectual ajudaram a produzir uma imensa e vasta bibliografia, que de acordo com Paim (1999)

\footnotetext{
"até os começos da segunda metade do século XVIII, a produção de autores brasileiros equivale a cerca de duzentos títulos. As obras literárias, de cunho histórico ou descritivas, bem como as de índole didática, técnica ou filosófica, oscilam em torno de
}

16 Denomina-se de movimento de Contra-Reforma a ação dos Jesuítas que tentaram reconstruir a escolástica medieval a partir do resgate do tomismo. A Reforma a que se colocam contrários diz respeito a chamada "reforma pombalina", quando o Marquês de Pombal, visando modernizar a Academia modifica o método de ensino regular, introduzindo diversos ramos das ciências que haviam sido proibidos pela Igreja (PAIM, 1999, pág. 44). As implicações disto na pedagogia são claras, dentre as mais evidentes: a abertura cognitiva. No plano político, entretanto, persiste um paradoxo. Tais ideias iam de encontro com a prática política da época pois se tentava estudar ciência a partir da realidade imperialista e fundada num direito divino de governar (PAIM, 1999, pág. 45). Isto reflete sobremaneira nas modificações que são propostas por Heinécio (1681-1741), Grócio (1583-1645), Pufendorf (1632-1694) e, no Brasil, Tomás Antônio Gonzaga (1772); operando-se, então, uma cisão na história do Direito Natural, pois agora falase de um Clássico e um Moderno. 
trinta. Toda a parcela restante poderia ser agrupada como apologético-religiosa, em sua maioria na forma de sermões" (PAIM, 1999, pág. 40).

Dessa cultura emerge uma proposta feita por Vita (1968) de que durante este período o Brasil estava imerso no que Max Scheler denominará de "saber da salvação" (PAIM, 1999, pág. 40). De acordo com o mesmo, existiam uma categoria de saberes técnicos e operativos denominados de saberes científicos, e ao lado deste haveria um segundo tipo de saber que não se refere à este mundo, mas sim ao outro (PAIM, 1999, pág. 40). Eles constituíriam a razão por detrás de toda a necessidade de compreensão e descrição do mundo, e, de acordo com Vita (1968) seriam a caracterísca mais aparente da segunda escolástica portuguesa na cultura brasileira. De acordo com Paim (1999) “o mundo não estaria aí para que os homens nele erigissem algo digno da glória de Deus (...), mas para tentá-lo. Desse modo, a resistência à tentação equivale ao comportamento ético por excelência. A transitoriedade da tentação opõe-se a eternidade da salvação". (pág. 41). Ainda, mais a frente conclui

\footnotetext{
"no que respeita ao saber da salvação e em geral à bibliografia do período, conviria fazer uma distinção entre obras apologéticas dirigidas aos ateus, cujo paradigma nos poderia ser dado pelos Pensamentos, de Pascal; obras de espiritualidade, predominantemente místicas e de intenção edificante (sermões, etc.); obras de cunho moralizador, casuístico e intenção pedagógica, tendo em vista a formação das almas e a direação das consiências; e, finalmente, as obras teológicas propriamente ditas". (PAIM, 1999, pág. 42).
}

Este é o retrato da influência da Segunda Escolástica portuguesa na cultura brasileira. Cite-se, questão importante a se tratar, que não haveria faculdades no Brasil até 1826, então, de fato, o monopólio do pensamento (e da pedagogia) era exclusivo dos centros eclesiásticos. Aqueles que procuravam fazer ciência e reformar o pensamento teriam que se deslocar para Portugal, Coimbra ou Lisboa. Não se pode esquecer, também, que apesar de ser este o pensamento dominante durante grande parte da história inicial do pensamento no Brasil, já havia notícia do estudo de Kant entre 1804 e 1810 (através do magistério de Martim Francisco) a tradução da obra de Charles Villers de 1801 (PAIM, 1999, pág. 55). Infelizmente, estes estudos permaneceram escondidos e afastados do público por uma clara intenção centralizadora da coroa portuguesa nas terras brasileiras. 
O povo brasileiro incapacitado de produzir uma revolução epistêmica, científica, política ou social se volta para a cultura como modo de crítica da realidade religiosa. Era, como diz Rainer Sousa em pequena crônica publicada em página da internet: a europeização da literatura, música, pintura, etc. que tomava conta do cenário artístico no Brasil como forma de contraposição ao ideário do saber da salvação. A realidade jurídica não era tão distante disto. Como os magistrados que exerciam o mister de Juízes não poderiam estudar no Brasil, todos estudaram em Portugal e ficaram no meio do fogo cruzado entre a Reforma Pombalina e a Contra-Reforma Jesuíta. De fato, o Direito Natural era o paradigma a ser visitado, e um dos motivos que nos leva a crer que não há um abandono disto pela tradição brasileira é o estudo do "saber da salvação".

A partir da criação das Faculdades de Direito (e especificamente delas), a filosofia começa a ser discutida dentro de uma Academia. Porém, um grave fator acomete as considerações deste ciclo de investigação científica. Por meio de Decreto, durante as décadas de 1850 à 1880, Dom Pedro II torna obrigatória e elege como filosofia oficial do Império Brasileiro o Ecletismo Espiritualista. Este tipo de posição filosófica buscava agregar teses aparentemente antagônicas buscando pontos de conciliação, daí porque eclética. E o adjetivo espiritualista estaria sendo utilizado a fim de estabelecer os pontos de diálogo entre as diversas filosofias do espírito (mas, de cunho eminentemente tomistas por conta da tradição do pensamento), com as novas filosofias mais cartesianas e mecanicistas (a exemplo a física, a química, etc.). O Direito Natural neste sentido ganha uma nova perspectiva, novas possibilidades. Nesse sentido,

\footnotetext{
"Os pensadores ecléticos passam a colocar em primeiro plano o problema da moral, que Biran não resolvera de forma satisfatória e permanecia um desafio para o espiritualismo em seu conjunto, inclusive os intentos de restauração da escolástica. Precisamente essa circunstância faz sobressair a importância do livro Fatos do Espírito Humano (1885), de Gonçalves de Magalhães, logo traduzido ao francês e recebido em Paris como contribuição relevante à solução do problema que a todos preocupava". (PAIM, 1999, pág. 58).
}

Desde seu nascedouro, o ecletismo espiritualista esta ligado ao pensamento escolástico no Brasil. Reputa-se à Frei José do Espírito Santo a realização dos primeiros estudos ligados ao pensamento eclético no Brasil, padre franciscano lecionou as ideias ecléticas nos Seminários da Bahia por volta do ano de 1842 (PAIM, 1999, pág. 60). Tal dourina, que a época vivia seu apogeu na França, tinha como expoentes Maine de Biran, Victor Cousin e Theodore Jouffroy. Dois brasileiros se destacaram na compreensão destas teses, viajando para França a fim de aprender com os expoentes desse pensamento, são eles: Salustiano Pedrosa 
e Gonçalves de Magalhães. Magalhães, incluse, escreve carta cujo teor acusa a relação dos ecletistas com o Direito Natural, quando argumenta que

\footnotetext{
"Passando agora à Filosofia, Ihe direi que M. Jouffroy está publicando sua lições de Direito Natural; eu tenho assistido a elas e posso assegurar-Ihe que são muito filosóficas; ele desenvolveu da maneira mais clara e precisa o sistema de Spinoza, assim como o ceticismo e o misticismo; ele se mostra digno sucessor de Royer-Collard e ótimo discípulo de Cousin" (MAGALHÃES apud PAIM, 1999, pág. 60-1).
}

Magalhães foi alvo de duras críticas pela Escola do Recife. Em dois textos, Tobias Barreto de Menezes sustenta posições que afastam a incidência da filosofia moral espiritualista na compreensão do fenômeno jurídico. Para Tobias, o ecletismo espiritualista (e o naturalismo que se esconde por detrás desse manto) não é ciência pois subjetiviza o objeto ao arbítrio do cientista. A concepção de amor não pode ser medida, ou, sequer explicada no ato da descrição do objeto científico. Ele cita o sentimento do cientista em relação a uma rosa e do mesmo modo o de uma bela moça ao receber a mesma rosa. Este debate entre os dois configura-se numa das contendas mais importantes para a filosofia brasileira na medida em que Tobias insere no pensamento acadêmico brasileiro uma crítica ao espiritualismo e ao Direito Natural através de um método reducionista acusando uma parcial adesão ao positivismo (muito embora algum tempo depois critique a apropriação brasileira ao positivismo por acreditar existir uma incompreensão de Kant - dentre outros - no Brasil).

Estes anseios de modernização intelectual fizeram com que o Direito Natural perdesse força no Brasil tendo o mesmo sido paulatinamente substituído pelas contemplações científicas do Direito Positivo. Movimento similar ao que se deu em âmbito macro após a publicação do trabalho de Savigny e Gustavo Hugo. A questão, que também pode ser acometida do ponto de vista do humanismo, conforme leciona Bárbara Lessa (2016), "em relação ao direito natural e aos direitos naturais, os humanistas consideravam difícil e até mesmo inútil sustentar a existência de um direito natural” (pág. 12). O que importava eram as leis e as consequências das práticas humanas que estavam em jogo.

Neste diapasão cabe ainda salientar e traçar uma linha temporal para a compreensão desses momentos sob os quais o Direito Natural perpassa no Brasil, como forma de conclusão preliminar deste tópico: a) do descobrimento até a reforma pombalina o Direito Natural passou por um amplo resgate da tradição tomista, fixando suas bases na cultura brasileira; b) a partir da reforma pombalina o Direito Natural passou por uma modernização de seus dogmas e paradigmas para que pudesse transparecer no 
Brasil na forma de ecletismo espiritualista; c) a partir da crítica da Escola do Recife o Direito Natural começa a perder a significância por conta da instituição de um paradigma positivo.

\section{Tobias Barreto de Menezes e sua obra.}

De posse de toda esta argumentação fica clara a importância da obra tobiática para a construção de uma identidade jurídica no Brasil. Grande parte de seus escritos são condensados post mortem, considerando que aquela altura não havia periódicos acadêmicos, ou, revistas qualificadas. Consequentemente artigos esparsos publicados em jornais, palestras, discursos, são o arcabouço do pensamento de Tobias Barreto. O Estado do Sergipe publicou grande parte destes estudos reunidos e surgiram diversos comentadores e verdadeiros herdeiros do legado que se instituiu a partir do conhecimento deste pensador brasileiro. Bem, utilizaremos como arcabouço para o desenvolvimento deste tópico a compilação feita pelo Instituto Nacional do Livro MEC, com introdução de Paulo Mercadante e Antônio Paim (1977).

Nele está bem clara a divisão perpetrada no pensamento de Tobias, o sumário é divido temporalmente, nos artigos publicados entre 1868 e 1874 como relativos ao seu período de formação sua crítica ao naturalismo (na forma do ecletismo espiritualista) e adesão parcial ao positivismo. São cerca de dez artigos que compreendem temáticas relativas a: a) Crítica ao Tomismo; b) Crítica ao Ecletismo a partir de Guizot e Gonçalves de Magalhães; c) Crítica à metafísica clássica, dentre outros. Já no período de 1875 á 1882 a sua fase do rompimento com o positivismo. Constam seis trabalhos relativos à: a) reconsideração da metafísica; b) o papel da arte no desenvolvimento da ciência; c) desenvolvimento de uma teoria agnóstica da pena; d) a incompreensão de Kant no Brasil. Passemos à análise destes argumentos.

\subsection{Adesão Parcial ao Positivismo.}

Ao iniciar sua crítica, Tobias Barreto (1977) indica que as bases do pensamento ecletista constituem o alicerce no qual se fundou a filosofia da modernidade, porém, suas críticas ao ecletismo são (pelo menos preliminarmente), de cunho epistêmico e metodológico (pág. 58-60). Sustenta ele que o chamado ecletismo se funda, em essência, na tradição religiosa que tenta se modernizar com o emprego de um método científico moderno, nesse sentido, a constatação de Tobias (1977) se conecta com os reflexos da Reforma Pombalina que, mesmo depois de muito tempo, consegue cientificizar a religião através da filosofia (pág. 60). 
Essa incompatibilidade metodológica é acusada por Tobias como sendo o "radical defeito" do ecletismo, sustentando que "as ciências diversas que procuram o conhecimento das coisas têm cada uma o seu caráter pela mesma especialidade do seu objeto, e o que determina esse caráter é o emprego do método conveniente á aquisição das verdades respectivas" (MENEZES, 1977, pág. 60). Esta alegação dá um indício de que ele pretende atacar a episteme do ecletismo. Essencialmente, ele acusa que sob a perspectiva espiritualista persiste uma confusão entre os limites objetivos imantes a noção de um sujeito e um objeto.

Se de um lado as ciências naturais clarificam a relação entre sujeito e objeto a partir da percepção deste sobre a experiência daquele, as causas espirituais que também são experiências se apropriam da relação interpretativa para inserir a visão particular do sujeito na significação do objeto, desse modo dissimulando o método interpretativo das ciências naturais dentro das ciências do espírito no intuito de reduzir tais experiências em leis universais (MENEZES, 1977, pág. 61). A tímida noção que podemos construir com esta argumentação inicial de Tobias (1977) é a de que ele pretende atacar o espiritualismo pela impossibilidade de fusão de métodos entre o conhecimento do corpo e o do espírito (dando uma especial primazia para psicologia). A adesão parcial ao positivismo (em sentido filosófico) fica mais evidente nesse contexto, porém a crítica continua em outras obras e escritos.

Em outro momento, dissertando acerca da doutrina de São Tomás de Aquino, Tobias (1977) inicia argumento que coloca em xeque a validade autoritária da filosofia durante a Idade Média e o fato de, ainda no século XVIII, persistem os fervorosos defensores de tal tese (pág. 67-8). Nessa perspectiva a separabilidade entre religião e ciência também começa a ser acusada pelo jurista brasileiro, ponderando, dentre outras coisas que "o positivismo tem razão quando julga inacessível e intratável a questão da causa primeira, é crível mesmo que todos os desatinos metafísicos e teológicos sejam a fatal consequência de querer-se conter a divindade no círculo das investigações científicas" (MENEZES, 1977, pág. 69).

Ele sustenta que toda a construção da causa primeira do conhecimento (enquanto Deus), necessita de um critério validador interno (ao ser) que possui uma característica eminentemente moral: amor à divindade (MENEZES, 1977, pág. 71). Há também a acusação da impropriedade argumentativa na tese de Deus como a ideia central que se chega através da inteligência particular, vindo Tobias a sustentar que tal tese levaria, em última ratio, a um panteísmo de Deus (MENEZES, 1977, pág. 73). Ao fim de tudo isto, podemos auferir que a crítica de Tobias (1877) se associa ao processo de desontologização das ciências humanas por uma análise crítica, neutra e avalorativa. Daí decorre a necessária crítica ao naturalismo, que vem a ser completada com a afirmação de que "teologia e teodicéia não são ciências" (MENEZES, 1977, pág. 77). 
Após a publicação destes escritos, Tobias (1977) é respondido por Manuel Godofredo Autran que defende uma apropriação por parte de Tobias da tese aquiniana e começa densa crítica a respeito da intuição do saber como uma questão que pode sim ser presumida da existência divina. $\mathrm{O}$ amor que se sente por Deus pode ser objeto de ciência. Argumento este que é novamente combatido, sustenta Tobias (1977) que "é falso que para sentir seja necessário conhecer o que se sente (...) a consciência dá o conhecimento do que se sente; para conhecer é mister que essa coisa exista, mesmo antes de ser conhecida" (pág. 79) concluindo mais a frente com a metáfora: "o recém-nascido não tem consciência do que sente, mas a sente dor que o faz chorar" (pág. 79). Voltam as questões metodológica e epistemológica, apesar de extensa a transcrição é necessária:

\begin{abstract}
"O conhecimento é particular, fenomenal, determinado; a ciência é geral, baseada em princípios. $O$ individual, encarnado em si mesmo, não pertence à ciência; o que nos indivíduos ela procura é o que eles têm em geral e comum aos gêneros, às diversas classes de seres ou de fatos. $O$ amor que se tem de Deus é um fenômeno particular do espírito; como tal cai sob as vistas da consciência, mas não é ainda por si só um objeto científico; o amor pertence à classe dos fenômenos sensíveis, e estes por sua vez à classe dos fenômenos espirituais em geral, sobre que se exerce a psicologia empírica" (MENEZES, 1977, pág. 80).
\end{abstract}

O sentimento valorativo individual sobre o significado do objeto é irrelevante para a compreensão de sua existência e não pode ser presumido partindo-se do pressuposto da vontade daquilo que não se pode comprovar a existência, assim como não se pode alegar que a maior parte das pessoas concordaria que o amor que se sente por Deus é objeto, sim, de ciência (MENEZES, 1977, pág. 82). Ao passo que a própria ciência passa a ser conceituada como um espécie de estudo interno dos fatos, catalogação, generalização, sendo necessária a reflexão sobre o que se pretende conhecer (MENEZES, 1977, pág. 83). Curioso notar que Tobias (1977) não é cego para as regras internas da teologia e da teodicéia, pois concebe a distinção entre uma teologia moral e uma dogmática, porém ás descredita completamente enquanto ciências pelos postulados metodológicos e epistêmicos apontados durante todo o texto (pág. 89).

Somente em 1869, Tobias (1977) irá tratar da sua grande crítica ao Ecletismo Espiritualista quando ataca o livro "Fatos do Espírito Humano" de autoria do carioca Gonçalves de Magalhães. Aquelas alturas a brochura era o único (e o primeiro) manual de filosofia escrito no Brasil, tornando-se alvo para as mais diversas posições (pág. 90). A crítica desenhada por Tobias (1977) neste ensaio beira um argumento ad homini, quando ataca as escolhas dispositivas da retórica de Magalhães, acusando de acreditar ter descoberto algo novo na filosofia (pág. 92), mesmo não conhecendo inteiramente os reflexos da filosofia 
alemã na França, ou, quiça, na obra de Victor Cousin (pág. 94). É uma questão de referência, e uma escolha discricionária por alocar a verdade na visão exclusiva de um autor referência, sustenta Tobias (1977)

“O positivismo na Europa se exprimia por órgãos tais como Littré e Stuart Mill. O hegelianismo era atacado por muitos, sustentado e professado por Vera. Na Itália, onde o nosso filósofo estivera como encarregado de negócios, fulguravam os grandes nomes de Gioberti e de Rosmini. No mundo filosófico fazia-se ouvir o embate das mais fortes discussões movidas pelos mais robustos combatentes. E no entanto o Sr. Magalhães nada ouviu! Não se pode, não se deve desculpar ao ilustre filósofo-poeta-diplomata semelhante indiferença; tanto mais quanto ele, deixando o que melhor importava, ocupou-se muito de refutar o refutado, usando de velhos e debilíssimos argumentos". (MENEZES, 1977, pág. 94).

Tobias (1977), entretanto, dirige-se especificamente ao capítulo VIII da obra de Magalhães para investigação da teoria do duodinamismo como sendo aquela "que tira a sensibilidade da alma espiritual para atribuí-la a um princípio diverso" (pág. 94). Gonçalves de Magalhães visa distinguir, além das categorias "corpo" e "alma" uma terceira, a sensibilidade como um a priori para qualquer tipo de conhecimento humano, a resposta de Tobias (1977) ainda reside no fato de que a ciência não pode deixar de falar uma linguagem específica e excluir de sua apreensão a língua comum, do cotidiano, ou seja, a premissa maior para derrubar o primado da sensibilidade é a simples apreensão de que ela não passa de uma intuição, um palpite, um exercício divagatório quando não mensurada e reduzida a um método (pág. 95-7). Com estas acepções da crítica de Tobias (1977) ao Ecletismo, percebe-se sua aproximação com um positivismo metodológico. É bastante dizer que ele foi fortemente influenciado neste período pelo primeiro Ihering, portanto, um adepto da positivação, simplificação e esvaziamento ontológico do Direito.

\subsection{Crítica aos Positivistas.}

Em 1875, Tobias (1977) lança texto, muito por conta da publicação de seu grande amigo e seguidor Sylvio Romero intitulada "A morte da metafísica", respondendo-a com o seguinte título: "Deve a metafísica ser considerada como morta?" (pág. 291). Nesse sentido, ele postula, ainda que novamente, pela tese de superação da teologia e da fé implícita no "velho Deus" que ainda é o argumento comum sustentado pelos grandes nomes da filosofia brasileira (MENEZES, 1977, pág. 291). Tobias (1977) procura sustentar a construção da morte da metafísica através da complementação de Kant à crítica feita por Hume, desde já frisando que todos os desenvolvimentos do tema se dão dentro da filosofia alemã, não somente isso, ele associa a obra de Hermann Hettner como sendo o pressuposto da crítica de Kant, sustentando a queda do absoluto e a superação da metafísica e da teologia pela experiência (pág. 292-3). 
Refere-se ele ao pressuposto das críticas da razão pura e prática, da possibilidade de moldar o mundo da natureza pelo mundo da cultura e a questão da conduta é completamente levada a cabo pelo prospecto do ideal de libertação do sono dogmático. Tobias (1977) se põe divagante nesse princípio kantiano e conclui que a apreensão da na causalidade pela humanidade diz respeito à consciência e ela é pura metafísica, nesse sentido, seria mesmo possível advogar uma tese de morte da mesma estando ela presente como dado essencial para compreensão da natureza e das humanidades? Essa é a primeira crítica tobiática ao que se tornou o positivismo jurídico no Brasil (pág. 294-7).

Nota-se que Tobias (1977) está operando num quadrante que diz respeito ao desenvolvimento hegeliano das premissas kantianas da crítica da razão, ele está se filiando ao fato de que a partir da intencionalidade do ser as ciências se dividem em natureza, razão e espírito, este último o centro onde se desenvolvem as instigações do espírito objetivo, subjetivo e absoluto. Outrossim, Tobias (1977) está a criticar uma apropriação do pensamento kantiano de modo a acreditar num esvaziamento completo e desmedido da questão metafísica de dentro das ciências, parece comungar com um ideal que só viria a ser postulado em sua inteireza em 1934 na Teoria Pura do Direito, a ciência do direito como uma verdadeira ciência do Espírito. Nesse sentido a crítica de Tobias é substancial, um equívoco interpretativo, uma apropriação dos conceitos fundamentais de Kant pela tradição jurídica instituída a partir da Escola do Recife.

\section{Conclusões.}

Em sede de conclusão podemos apontar que: a) a crítica de Tobias ao Naturalismo é uma uma crítica metodológica baseada nos pressupostos de Hume e com influencias Kantianas; b) a crítica de Tobias ao positivismo é substancial pois ataca de frente um erro interpretativo, uma falha na compreensão da estrutura do pensamento neo-kantiano, especialmente em Hegel. Acusar isso é esclarecer que, de fato, é pertinente a adesão parcial e a crítica ao positivismo jurídico fundado a partir da premissa da morte da metafísica. Neste diapasão, Tobias (1977) está coberto de razão. Não podemos sistematizar e objetivar a ciência ao extremo acreditando que a simples alegação de não existência de uma lei natural, implica, necessariamente, uma não existência de uma lei da natureza. Ao mesmo passo, de que o papel e a linguagem do cientista é uma linguagem da matemática e da certeza, da causalidade.

O que Tobias (1977) indica, simplesmente, é o de que os franceses se debruçam sobre Kant mas Kant não é objeto de divagação por parte dos juristas brasileiros. Parecem ser cegos e atrasados para os contributos do racionalismo e se o são, também parecem desconhecer completamente os desenvolvimentos do neo-kantismo. Este é o epicentro da resposta dele a toda uma escola que se formou sobre a tese de necessidade de objetivação da ciência pela razão. 
Conhecer isto é compreender melhor a formação e a construção dos dogmas jurídicos no Brasil. Pode-se perceber porque Kelsen, por exemplo, é um autor incompreendido pela tradição brasileira. Desde a raiz estamos completamente vinculados a uma necessidade de objetivação extrema das relações sociais e esquecemos da nossa história quando tentamos compreender a nós mesmos. Esse é o problema essencial da teoria do direito e da tradição jurídica no Brasil. Mais vale um Dworkin na mão do que um Tobias, ou um Reale no bolso.

Enquanto não pudermos ser capazes de desmistificar esses dogmas instituídos pela incompreensão da Tradição jurídica brasileira estaremos completamente perdidos. Teremos avançados na "modernização" do direito pátrio como uma cópia de sistemas estrangeiros, debatendo realidades completamente diferentes da nossa e estaremos atrasados no reconhecimento da nossa identidade jurídica.

\section{Referências Bibliográficas.}

ALEXY, Robert. O Conceito e Validade do Direito. Org. Ernesto Garzón Valdés, Hartmut Kleimt, Lothar Kuhlen e Ruth Zimmerling. Tradução Gercélia Batista de Oliveira Mendes. Revisão da tradução por Karina Jannini. Editora Martins Fontes. São Paulo - SP. 2011.

ARISTÓTELES. Metafísica. Textos adicioais e notas Edson Bini. 2ª Ed. São Paulo: EDIPRO, 2012.

AUSTIN, John. Lectures on Jurisprudence or the Philosophy of Positive Law, 2 vols., 5 ed., Londres. 1861.

AZEVEDO, Antônio Junqueira. Influência do Direito Francês sobre o Direito Brasileiro. Conferência proferida em Paris, em 26 de novembro de 1993, a convite da Universidade de Paris II. Disponível em: $<\underline{w w w . r e v i s t a s . u s p . b r / r f d u s p / a r t i c l e / d o w n l o a d / 67243 / 69853}>$. Acesso em: 01.04.2014.

BARRETO, Luis Antônio. Tobias Barreto (1839-1889) - Biografia e Estudos Críticos. Centro de documentação do pensamento brasileiro. Disponível em: <http://www.cdpb.org.br/tobias barreto.pdf> Acesso em 01.04.2014.

BARROS, José D'Assunção. Teoria da História - Os Primeiros Paradigmas: Positivismo e Historicismo. Volume II. Petrópolis, RJ: Vozes, 2013.

BOBBIO, Norberto. O Positivismo Jurídico: lições de Filosofia do Direito. Compiladas por Nello Morra; tradução e notas por Marcio Pugliesi, Edson Bini, Carlos E. Rodrigues. São Paulo, Ícone. 1995.

COING, Helmut. Las Tareas del Historiador del Derecho (Reflexiones Metodológicas). Publicaciones de la Universidad de Sevilla, 1977 In GONZALEZ, Maria del Refúgio. Historia del Derecho (Historiografia y Metodologia). Universidad Autonoma Metropolitana. 1977.

DILTHEY, Wilhelm. Introdução ao Estudo das Ciências Humanas - Tentativa de uma fundamentação para o estudo da sociedade e da história. 2a Ed. Tradução e prefácio Marco Antônio Casanova. Rio de Janeiro. Forense Universitária. 2010. 
Hermeneutics and the Study of History. Selected Works. Volume IV. Edited with an introduction by Rudolf A. Makkreel and Frithjof Rodi. Princeton University Press. Princeton - New Jersey. 1996.

DWORKIN, Ronald. Taking Rigths Seriously. Harvard University Press. Cambridge, Massachusetts. London, England. 1978.

. Law's Empire. Harvard University Press. Cambridge. Massachusetts. London, England. 1986.

GADAMER, Hans-Georg. Verdade e Método - Traços fundamentais de uma hermenêutica filosófica. Tradução de Flávio Paulo Meuer. 3a Edição. Editora Vozes. Petrópolis - RJ. 1999.

HART, Herbert. O Conceito do Direito. Ed. Pós-escrito e organizado por Penelope A. Bulloch e Joseph Raz. Tradução de Antônio de Oliveira Sette-Câmara. Revisão de tradução de Marcelo Brandão Cipolla. Revisão técnica de Luiz Vergílio Dalla-Rosa. Ed. Martins Fontes. São Paulo - SP. 2012

GRINBERG, Keila. Interpretação e Direito Natural - Análise do Tratado de Direito Natural de Tomás Antônio Gonzaga. Disponível em: <http://www.revistas2.uepg.br/index.php/rhr/article/view/2025> Acesso em: 10 out. 2016.

HIMMA, Kenneth. Inclusive Legal Positivism. Oxford Handbook of Jurisprudence and Philosophy of Law. Oxford University Press. 2002.

KELSEN, Hans. A Teoria Pura do Direito. Tradução João Baptista Machado. 7ạ ed. Martins Fontes. São Paulo - SP. 2006.

LESSA, Bárbara Alencar Ferreira. O Tratado de Direito Natural de Tomás Antônio Gonzaga: Uma Análise Histórica do Conceito de Direito Natural. Disponível em:

<http://www.publicadireito.com.br/artigos/?cod=297fa7777981f402> Acesso em: 10 out. 2016.

MARMOR, Andrei. Legal Positivism: Still Descriptive and Morally Neutral. Forthcoming in the Oxford Journal of Legal Studies. USC Legal Studies Research Paper No. 05-16. Legal Studies Research Paper Serires. Disponível em: <http://ssrn.com/abstract=763844> Acesso em: 01.04.2014.

MCINERNY, Ralf. Foreword to the English Version. In: DI BLASI, Fulvio. God and the Natural Law; a rereading of Thomas Aquinas. South Bend: St. Augustine Press, 2006.

MENEZES, Tobias Barreto de. Ensaios e Estudos de Philosophia e Crítica por Tobias Barreto de Menezes. 2a Edição correcta e augmentada. Editor José Nogueira de Souza. Pernambuco - PE. 1889. Disponível em: <www.dominiopublico.com.br> Acesso em: 01.04.2014.

. Obras Completas IV: Discursos. Edição do Estado de Sergipe. Decreto n. 803 de 20 de Abril de 1923. Sergipe - SE. 1929. Disponível em: <www.dominiopublico.com.br> Acesso em 01.04.2014.

. Estudos Allemães. Primeira Série. Typographia Central. Recife. 1883. Disponível em <www.dominiopublico.com.br> Acesso em 01.04.2014.

. Estudos de Filosofia. Introdução de Paulo Mercadante e Antônio Paim. Em convênio com o Instituto Nacional do Livro - Ministério da Educação e Cultura. 2a Edição. Editorial Grijalbo. Recife. 1977.

MOURA, Odilão. A Doutrina do Direito Natural em Tomás de Aquino. Revista Jurisp. Mineira. Belo Horizonte, a 55, n. 169, p. 21-41, abril/junho. 2004. Disponível em:

<http://bd.tjmg.jus.br/jspui/bitstream/tjmg/644/1/D2v1682004.pdf> Acesso em: 10 out. 2016.

PAIM, Antônio. Os Intérpretes da Filosofia Brasileira - Estudos Complementares à História das Ideias Filosóficas no Brasil. Volume I. 3ạ Ed. Editora UEL. Londrina. 1999. 
SANTOS, Boaventura Souza. A Crítica da Razão Indolente: Contra o Desperdício da Experiência. Porto: Afrontamento, 2000 (2a edição). Também publicado no Brasil, São Paulo: Editora Cortez, 2000 (7ạ edição).

SCHLEIERMACHER, Friedrich D. E. Hermenêutica - Arte e técnica da Interpretação. Tradução e apresentação de Celso Reni Braida. Editora Vozes. Petrópolis - RJ. 2000. 